\title{
Drawing (Upon) Human Rights: Reading the Illustrated Version of the UDHR
}

\author{
Pramod K Nayar*
}

\begin{abstract}
This essay examines the illustrated version of the Universal Declaration of Human Rights. The use of stickfigures, it argues, is a verbal-visual discourse that performs the human subject as an anonymous yet identifiably human person. Emphasising the constructed nature of the human, the combination of text and image functions as an instance of 'expository discourse'. In the second section of the essay I propose that the UDHR's illustrated version uses the aesthetics of 'figurative realism' wherein the representation of the human person as a stick means that we see a figure who stands in for the person. It concludes by arguing that these minimalist representations signal the UDHR's foundational nature rather than its simplicity. The UDHR's reliance on the drawn line forces attention to the process, the mechanics by which we make human persons, or unmake them.
\end{abstract}

Keywords: UDHR, Figurative Realism, Discourse, Human Rights

\section{Introduction}

The Universal Declaration of Human Rights (1948, hereafter UDHR) is arguably one of the most visible, significant and translated documents in the history of mankind. It has now been rendered into a 72-page illustrated account by the United Nations, with drawings by Yacine Ait Kaci (2015).

*The University of Hyderabad, India; pramodknayar@gmail.com 
The essay assumes that any document that enables the making of a 'planetary geoculture' (Elias \& Moraru cited in Ghosal, 2018, p. 184) around the universal and universalising theme of Human Rights (hereafter HR) must evolve strategies through which this key text may be communicated to the entire globe. A planetary geoculture is one where 'globalisation's homogenising, one-becoming pulsion is challenged by relationality, namely, an ethicisation of the ecumenic process of coming together or worlding' (cited in Ghosal, p. 184). A planetary geoculture, of course, assumes a basic level of literary competence to interpret both text and image, but over and beyond this basic competence, the illustrated UDHR experiments with the form in which the concern with HR may be effectively communicated. I propose that the UDHR takes recourse to specific narrative and rhetorical modes to literally illustrate its thirty articles. While the text of the UDHR remains unchanged, it is Kaci's illustrations read in conjunction with the verbal text that evokes our affective understanding of HR.

The UDHR booklet, appropriately, uses a stick figure to represent the human - gender, race and ethnicity unmarked, symbolising the universal human.

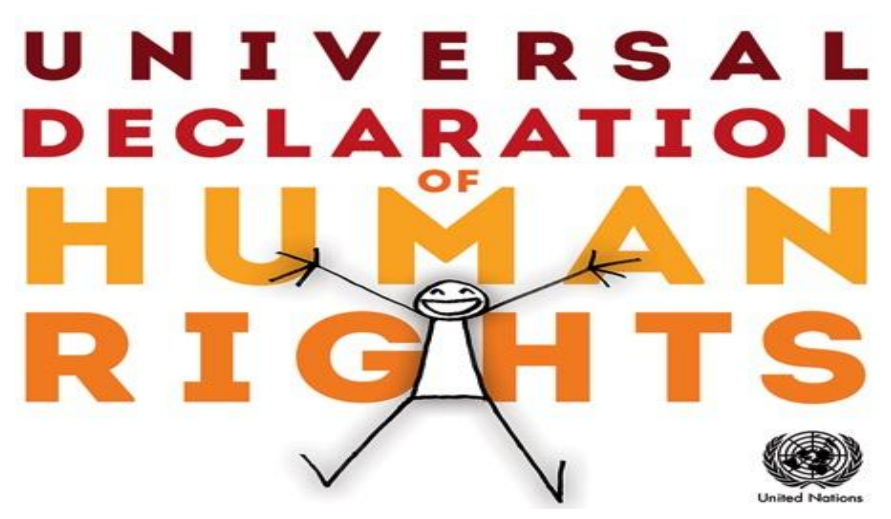

Fig 1: Cover page of the UDHR (illustrated edition)

Two observations need to be first enunciated about the use of stick drawings in this document. First, this stick figure is any-body and every-body. Second, given the increasing familiarity with chatbots and robots in everyday life via computer-mediated communication humans have learnt to interact with these instances of embodied software, and even accepting a robot's 'level of "humanity"', as one 
commentator puts it (Westerman et al., 2018). This means, we have learnt to read emojis, chatbots, smileys as standing in for the human, and the UDHR simply extends this tendency and form of interaction that causes us to detect and discern humanity in the stick figures. There is, of course, the need for a human face, even if a generic one for, as writers on HR remind us, the face is the proof of humanness, and 'the norms of humanisation require a name and a face' (Butler, 2009, p. 95). The UDHR document gives us $a$ face in the form of the stick figures, but it could be any body's face.

\section{Discourse, the Performative and the Human}

Following Lauren Wilcox who proposes that security discourse may be treated as performative, 'producing and sustaining embodied subjects within a broader social order' (p. 29), then, I suggest UDHR's illustrated version is a verbal-visual discourse that performs the human subject as an anonymous yet identifiably human person. The verbal text of Article 1 speaks of the human being as the subject of rights. It says "All human beings are born free and equal in dignity and rights. They are endowed with reason and conscience and should act towards one another in a spirit of brotherhood". The image accompanying shows us a human person emerging (See Figure 2).

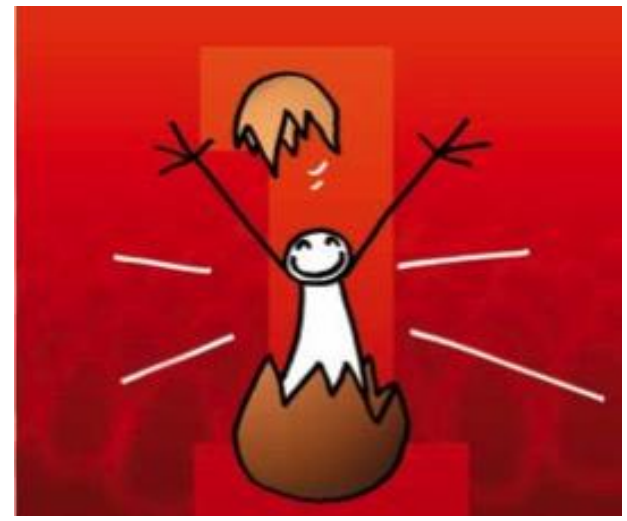

Fig 2: Image accompanying Article 1

The birthing metaphor in verbal and visual form literally performs the birth of the human as the moment of the birth of HR. That is, the image naturalises rights as a condition arriving with the birth of 
the human itself. However, the image also performs something more. By positioning the human as emerging from an egg, it draws attention to the vulnerability of the human, metaphorised as the fragility of an egg. Drawing upon the common knowledge of the egg's fragility, the image signals the fragility of the human and of rights - which, therefore, demands protection.

Now, the appeal to common knowledge - of the fragility of human birth, body and life in general, embodied in the egg-image - has the same level of acceptability as the appeal to popular opinion. David Godden has argued that

a claim to common knowledge is taken as grounds for its acceptability, whereas appeals to popular opinion are seen as fallacious attempts to support a claim. Against this I argue that appeals to common knowledge generally provide no better evidence for a claim than appeals to popular opinion and, as such, that appeals to common knowledge ought to be just as successful-or unsuccessful-as appeals ad populum. (2008, p. 102)

UDHR's illustrated version, I argue, appeals to both, the knowledge of an egg's fragility and the potential risk in birthing, and to the popular opinion of the egg as the moment of human origin. By merging two paradigms, common knowledge and popular opinion, the UDHR ensures that a discourse of overall human fragility and of natural rights are made visible. (One needs, of course, to read both text and image together here for effect.)

While the photograph universalises and metonymises one individual's experience (Allbeson, 2015), it also calls attention to the very act of drawing a person, of constructing a person as a stick figure. There is, Hillary Chute notes, a sensuous and subjective element to comics because it involves drawing, where the comics page is the material evidence of the body of the drawer (2016, p. 4, 20). Later, reading Nakazawa's cult Hiroshima text, I Saw It, Chute argues that the

hand-drawn form is a documentary counterinscription to the bomb as camera. A deliberately primitive technology that operates as a 
countermarking and countervisuality, its comics form signifies the bodily in the act of making marks against the techne of bodies marked and vaporized by the bomb's light. (p. 136)

Merging these two views, of two different media forms (photography and comics), we recognise the constructed nature of the human person in the frame of the medium. If this is indeed true, then the construction of stick figures as symbols of humans would enable the artist to show us how a person denied personhood would possibly look like. About the power of the photograph, Susie Linfield argues:

what photographers can do, and do peculiarly well, is to show how those without such rights look, and what the absence of such rights does to a person. And they can, and have, shown us what people struggling for rights look like, in victory and defeat. (p. 37, emphasis in original)

Linfield further proposes that, since the photograph doesn't itself explain, viewers 'must look outside the frame to understand the complex realities out of which these photographs grew' (p. 51). I propose that the image drawn in the UDHR is explained by the Articles of the UDHR.

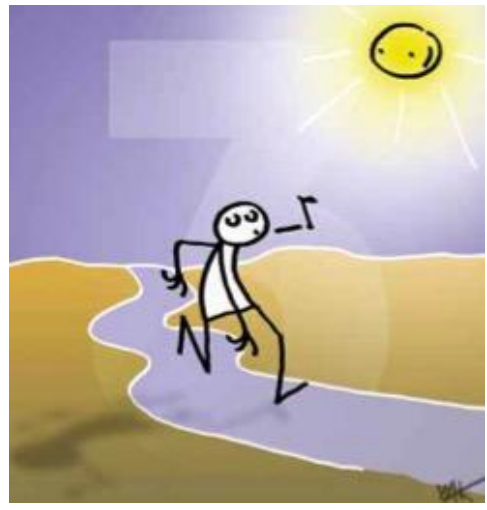

Fig 3: Image accompanying Article 3

The image could be of a marathon runner toiling away under the sun. The ghostly 3 in the background however cautions us: we see the runner through the numeral and the numeral as enclosing the 
runner, each framing the other, but also constituting the body of the other. We come to the image after the Article itself (images follow the verbal text in the document), and the Article reads:

Everyone has the right to life, liberty and security of person.

This text of the Article is the anticipation and explanation of the image, where the right to life, freedom and security belongs to all. The sun and the open road with no barrier or threat are available to the runner. The runner is free to utilise these, is at liberty to choose the path ahead. The image is drawn in the context of the verbal text. Take another instance, of Article 9. The image shows a person escaping a cage whose door is open. The text reads: 'no one shall be subjected to arbitrary arrest, detention or exile'. The text illuminates the image, explains it.

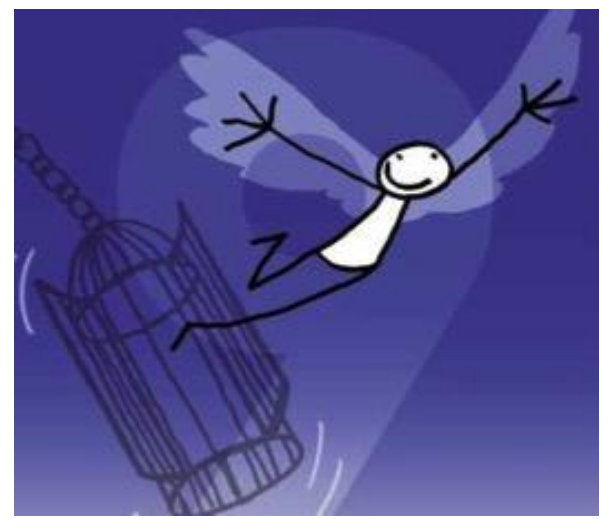

Fig 4: Image accompanying Article 9

The combination of text and image functions as an instance of 'expository discourse', defined by Mieke Bal as a 'discourse of display' where the narrator both tells us about and shows the object being discussed. Anna Szörényi, adapting Bal's work to read coffee table books on refugees, writes:

The world constructed by expository discourse is one in which those who speak are not visible, while those who are on display are not expected to speak. Expository discourse, including the display of photographs of 'others', is not only an exercise in 'humanising', or creating 'sympathy' for, those 
others, it also an exercise in defining the difference between 'us' and 'them'. 'We', the exposition implicitly argues, are those who look. 'They' are those who are looked at. (2006, p. 29)

I wish to tie Szörényi's point with Michael Ignatieff's when he argues that a HR campaign begins when somebody stands up to declare that her rights have been denied (2001). The combined logic of Szörényi's and Ignatieff's argument directs us to an interesting proposition.

The ones who are on display here in the UDHR document do not need to speak, because the UDHR Article is, in effect, what they embody. Embodiment is the materialisation of the speech, and the words of the UDHR's Articles. Thus, the runner embodies 'liberty', the person escaping the cage embodies freedom from arrest and/or detention - neither of them needs to declare 'I am free'. But in the process, the UDHR text-image forces us, the audience, to acknowledge that there are people not depicted here in the document who, by the combined logic of the Szörényi-Ignatieff argument, would have to speak because they do not experience these rights. That is, in the very act of embodying the non-speaking but free subjects, the UDHR displays, by implication and strategic absences, those who are not displayed here and who therefore must be speaking.

Having established that the UDHR's illustrated version is an instantiation of expository discourse that performs the human, I now turn, in the second section of the essay, to another interesting feature of the text.

\section{Figurative Realism}

I have elsewhere argued, in a reading of Igort's graphic novel, The Ukrainian and Russian Notebooks, that the 'figurative realist enables us to see the human behind the stick/shadow-figures and ghosts' (2018: 378, emphasis in original). In Igort's case, of course, the dying and ruined humans were the subject of the comics' figurative realism, so that we as readers visualised the wasting away of the humans into ghost-like figures. 
The representation of the human person as a stick means that we see a figure who stands in for the person. In sharp contrast to the realist mode of documentary comics (see Mickwitz, 2016), this is visual metaphorisation drawn in minimalist fashion. I suggest that the figurative realism of bare stick figures constructs the human too.

The stick figures force us to see humans behind and beyond the lines. But in the very effect of minimalist representation, it implies that these are the irreducible forms of the human: a human cannot be anything less than these stick figures. We cannot, in other words, take away these lines and expect the 'figure' or its remnants to resemble and recall a human. The stick figures are the blueprints for the person to come. They are the grounds upon which the edifice of the human has to be imagined, rather like the building plans which, when viewed, cause/enable us to visualise the entire structure. ${ }^{i}$ In other words, the stick figures are the basic building blocks of our imagining a human person, one who will then be deserving of rights. One does not, suggests the image, require a photograph of a human to imagine a human. With the barest set of lines, one can conjure up a human who then merits these rights.

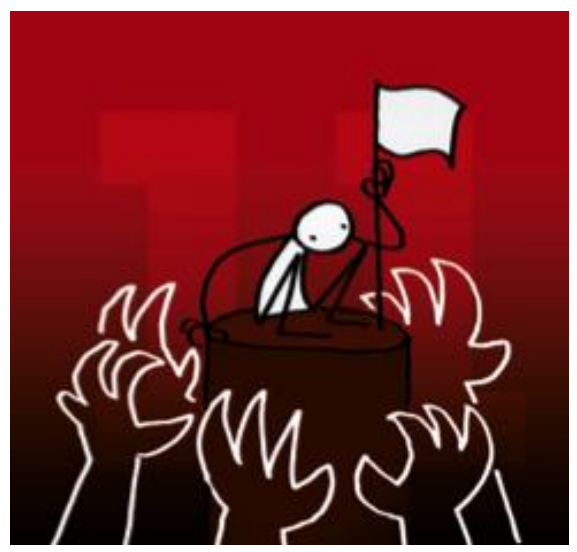

Fig 4: Accompanying Article 11

Take for instance the above image (Figure 4) accompanying Article 11 which reads as follows:

1. Everyone charged with a penal offence has the right to be presumed innocent until proved guilty according to law in 
a public trial at which he has had all the guarantees necessary for his defense.

2. No one shall be held guilty of any penal offence on account of any act or omission which did not constitute a penal offence, under national or international law, at the time when it was committed. Nor shall a heavier penalty be imposed than the one that was applicable at the time the penal offence was committed.

The image shows a figure under siege, surrounded by a sea of hands reaching out to grab. The 'person' squats at the base of a white flag (of surrender, or protection?). The text states that this person is entitled to a fair trial, and no penalty can be imposed which is not mandated by the law. It also indicates quite clearly that all penalties and punishments can only be imposed by the apparatus of the law, and that until proved guilty, the accused is deemed innocent. The grabbing hands are at once accusatory and threatening. Recalling the horrific images of lynching, the image suggests that the person is being accused or threatened or judged by an apparatus that is outside the ambit of the law (he is perched on a block that could very well be read as the symbol of a courthouse). The stick figure is a person under threat from the grabbing hands. The sole protection, witness or defence is the flag, under which this person crouches. There is little more here for us to read, but we understand one thing: there is a solitary, vulnerable person here whose bare existence is guarded by a bare frame of a flag.

Later, the basic requirements for a human to live with dignity are spelt out in Article 22:

Everyone, as a member of society, has the right to social security and is entitled to realisation, through national effort and international co-operation and in accordance with the organisation and resources of each State, of the economic, social and cultural rights indispensable for his dignity and the free development of his personality. 
Here is the accompanying image:

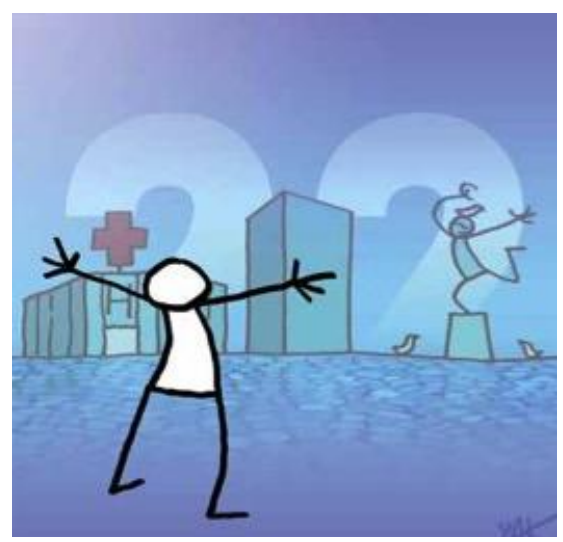

Fig 5: Accompanying Article 22

The arts (a statue or a dancer) representing cultural rights and the red cross emblem of the health services face the stick figure - who is either appealing to them or is in thrall with them, these social apparatuses of security and self-realisation.

The figurative realism of these minimalist images when read with the accompanying text invites the following interpretation. The bare minimum is also a human person, and this person also merits a minimal legal protection. The Articles, then, are the mechanisms offering the basic protection to a person: the right to life, liberty, security and legal protection. Just as the person cannot be reduced to anything less than the stick-frame, legal support and protection cannot be anything less than what the Articles state. When surrounded by the charges or threats to the human person's security, the barest protection, at least, has to be extended.

UDHR, then, is not an ambitious edifice or a grand rhetorical structure. The stylistic minimalism of the document's images read in conjunction with the text signals something foundational - a blueprint, the bare bones of the story, the framework for building. It is precisely by keeping it to this bare minimum that the UDHR signals its foundational role: this is where it begins, by imagining the human in her basic frame, by devising legal mechanisms that address this basic frame. Everything else has to follow, like a building upon a blueprint. ${ }^{i i}$ 
The UDHR's illustrated version is a blueprint that is also a performative. It constructs a minimal definition of the human person, and uses this person as the point of departure to think of basic protections. By 'reducing' the UDHR to these minimalist representations, the document signals its foundational nature rather than its simplicity. From those stick figures we imagine a human person, from the Articles we envisage HR.

The use of hand-drawn figures (rather than the photograph, as noted earlier) consciously calls upon us to reflect on the constructedness of the very idea of the human. To return to Hillary Chute: 'while the lines index the bodies of their makers, the images meditate less on the self, on subjectivity, than on observing history and experience' (p. 172). Studies of the role of photographs in HR campaigns (Lydon, 2018, for example) have argued for the centrality of the image, but the UDHR modifies this argument in significant ways. The UDHR's reliance on the drawn line forces attention to the process, the mechanics by which we make human persons, or unmake them.

\section{References}

Allbeson, T. (2015). Photographic diplomacy in the postwar world: Unesco and the conception of photography as a universal language, 1946-1956. Modern Intellectual History, 12(2), 383-415.

Butler, J. (2009). Frames of war: when is life grievable? Verso.

Chute, H. L. (2016). Disaster drawn: visual witness, comics and the documentary form. Harvard UP.

Ghosal, T. (2018). The page is local: planetarity and embodied metaphor in anglophone graphic narratives from south Asia. Comics studies here and now, 180-190. Routledge.

Godden, D. M. (2008). On common knowledge and ad populum:Acceptance as grounds for acceptability. Philosophy $\mathcal{E}$ Rhetoric, 41(2), 101-129.

Ignatieff, M. (2001). Human rights as politics and idolatry. In M. Ignatieff \& A. Gutmann (Eds.), Human rights as politics and idolatry, 3-98. Princeton University Press.

Linfield, S. (2010). The cruel radiance: photography and political violence. University of Chicago Press.

Lydon, J. (Ed.) (2018).Visualising human rights. University of Western Australia Press. 
Marin, L. (1984). Utopics: spatial play. (R. A. Vollrath, Trans.). Humanities Press.

Mickwitz, N. (2016). Documentary comics: graphic truth-telling in a skeptical age. Palgrave-Macmillan.

Moyn, S. (2018). Not enough: human rights in an unequal world. Harvard UP.

Nayar, P. K. (2018). From documentary realism to figurative realism: Igort's the Ukrainian and Russian notebooks and the Holodomor. Counter Text, 4(3), 362-381.

Szörényi, A. (2006). The images speak for themselves? Reading refugee coffee-table books. Visual Studies, 21(01), 24-41.

United Nations. (2015). Universal Declaration of Human Rights. Illustrated by Yacine Ait Kaci. United Nations.

Westerman, D., Cross, A. C., \& Lindmark, P. G. (2019). I believe in a thing called Bot: perceptions of the humanness of "Chatbots". Communication Studies, 70(3), 295-312. DOI: 10.1080/10510974.2018.1557233

Wilcox, L. B. (2015). Bodies of violence: theorizing embodied subjects in international relations. Oxford UP.

'I am adapting here Louis Marin's work in Utopics: Spatial Play (1984) where he proposes a link between the blueprints of a building and the architecture built on this plan/blueprint. Marin writes:

If architecture is the art of constructing buildings and/or organizing space in order to create a space where humans can live, what is its relationship to the text? If this act involves manipulating and arranging space into a system of spaces through an architectonics of "living space," what can be said of the connection between architecture and writing and drawing, discourse and blue- print, with signs arranged on a visible surface and constantly grouped and re-grouped, torn apart and rearticulated into new groups? It is not absolutely sure that a dwelling or a city is a discourse translating a blueprint into language, or a written surface transposing words and ideas (i.e., desires) into sketched figures. (p. 113)

iiSamuel Moyn has, however, argued that assuming HR to be solely about basic political freedoms is to ignore the political economy of rights, that unless there is a clear program directed at distributive economic equality, HR will far short. Moyn writes:

It is also a matter of greater consensus than ever that the high and equal status of human beings entitles them to some basic political freedoms, such as the rights to speak and to be free from torture. 
When it comes to what share people ought to get of the good things in life, however, consensus is much harder to achieve... But human rights do not necessarily call for a modicum of distributive equality. And a concern for human rights, including economic and social rights, has risen as moral commitments to distributive equality fell. $(2018$, p. 3$)$ 